\title{
Germination of Acacia harpophylla (Brigalow) seeds in relation to soil water potential: Implications for rehabilitation of a threatened ecosystem
}

Initial soil water conditions play a critical role when seeding is the primary approach to revegetate post-mining areas. In some semi-arid climates, such as the Brigalow Belt Bioregion in eastern Australia, extensive areas are affected by open-cut mining. Together with erratic rainfall patterns and clayey soils, the Brigalow Belt denotes a unique biome which is representative of other water-limited ecosystems worldwide. Apart from other environmental stressors, germination is governed by the water potential of the surrounding soil material. While previous studies have confirmed the high tolerance of Brigalow (Acacia harpophylla) seeds to a broad range of temperature and salinity, the question of how soil water potential triggers seed germination remains. In this study, we used three replicates of 50 seeds of Brigalow to investigate germination in relation to water potential as an environmental stressor. Solutions of Polyethylene Glycol (PEG 6000) were applied to expose seeds to nine osmotic water potentials ranging from soil water saturation (0 MPa) and field capacity $(-.01$ to $-.03 \mathrm{MPa})$ to the permanent wilting point $(-1.5 \mathrm{MPa})$. We measured germinability (number of germinated seeds relative to total number of seeds per lot) and mean germination time (mean time required for maximum germination of a seed lot) to quantify germination. Based on the empirical data of the germination we estimated the parameters of the hydrotime model which simulates timing and success of seed emergence. Our findings indicate that Brigalow seeds are remarkably tolerant to water stress, with germination being observed at a water potential as low as -1.5 MPa. Likewise, the average base water potential of a seed population (hydrotime model) was very low and ranged between -1.533 MPa and -1.451 MPa. In general, Brigalow seeds germinate opportunistically over a broad range of abiotic conditions related to temperature, salinity, and water availability. Direct seeding and germination of native plants on post-mining land may be an effective and economically viable solution in order to re-establish plant communities. 
However, due to their capacity to reproduce asexually, alternative rehabilitation approaches such as transplantation of whole soil-root compartments may become attractive for restoration ecologists to achieve safe, stable, and non-polluting ecosystems. 
1 Sven Arnold $^{1 *}$, Yolana Kailichova ${ }^{1}$, Thomas Baumgartl ${ }^{1}$

21 Centre for Mined Land Rehabilitation, The University of Queensland, Brisbane, Australia

3 Correspondence: Sven Arnold (s.arnold@uq.edu.au) 


\section{Introduction}

The Brigalow Belt is an extensive bioregion located between the subtropical coastline and semi-arid interior of eastern Australia (Arnold et al. 2013). Climatically and pedologically the bioregion is distinct from surrounding areas (Isbell 2002; Lloyd 1984), and as a consequence, its ecological and biodiversity attributes are unique worldwide (Johnson 1980). Rainfall events occur erratically, both between years and intra-seasonally, and the clayey soils have high fertility and good water holding capacities (Gunn 1984). Of the few plant species able to survive under these water-limited constraints (Connor \& Tunstall 1968), A. harpophylla (Brigalow) is the predominant one, from which the bioregion derives its name.

Since the 1950s, the delicate balance between soils and the native plant communities has been disrupted (Eyre et al. 2009) through clearance of Brigalow woodland for agricultural land use (cropping, grazing), which reduced the original extension of the bioregion dramatically (Arnold et al. 2013). Consequently, A. harpophylla dominant ecosystems have been listed as endangered under both state (Vegetation Management Act 1999) and national legislation (Environment Protection and Biodiversity Conservation Act 1999: EPBC Act) (DEWHA 2010). More recently, areas in the Bowen Basin (largest coal reserve in Australia) have been concurrently affected by surface mine developments. The legislative requirement to reclaim post-mining land to provide safe, stable, and non-polluting environments (Australian Government 2006) provides the opportunity to re-establish native Brigalow plant communities.

Re-vegetation typically comprises either passive regeneration or proactive management such as transplanting seedlings and mature stands (Musselman et al. 2012), tube stocking, or direct seeding. The latter may be an effective and economically viable solution in order to re-establish Brigalow plant communities (Engel \& Parrotta 2001; Lamb et al. 2005; Reichman et al. 2006). In this regard, seed germination is an important indicator of re-vegetation success as it represents the first stage of plant physiological response and development to environmental conditions. Seed germination can be controlled by a range of abiotic stressors of which temperature and salinity have only limited impact on $A$. harpophylla seeds within the ranges of 15 to $38^{\circ} \mathrm{C}$ and 0 to $20 \mathrm{dS} / \mathrm{m}$, respectively (Reichman et al. 2006). However, given the unique pedological and climatic conditions of the Brigalow Belt, the question remains how Brigalow seeds respond to changes in water availability from soil. This quantitative information is crucial for simulating timing and success of seed emergence, for example when applying the hydrotime model (Bradford 1990; Gummerson 1986).

Although being the major environmental stressor in the Brigalow Belt Bioregion, less information exists on the direct effect of soil water potential on germination of $A$. harpophylla seeds. Therefore, the primary aim of this study is to determine their germination response in relation to soil water potential. In this regard, we investigate whether reduced germination at high values of soil salinity is due to toxic rather than osmotic effects (Reichman et al. 2006). As a secondary goal and based on the empirical data of the germination trials we estimate the parameters of the hydrotime model for A. harpophylla. Finally, we discuss our findings in the context of previous seed germination trials and alternative opportunities to reestablish plants on post-mining areas under water limited conditions. 
2 Materials and Methods

\section{$43 \quad 2.1$ Experimental design}

44 We used seeds ${ }^{1}$ of $A$. harpophylla to investigate germination in relation to water potential as 45 environmental factor. Three replicates of 50 seeds per treatment (i.e., water potential) were placed at equal 46 distance on an absorbent substrate (Wettex ${ }^{\circledR}$ ). Materials (e.g., tweezers, Wettex ${ }^{\circledR}$, glassware) were 47 autoclaved for 20 minutes at $121^{\circ} \mathrm{C}$ and preparation of treatments as well as any monitoring took place in 48 a laminar flow cabinet. All treatments and replicates were then placed randomly within a germination 49 cabinet under constant temperature $\left(25^{\circ} \mathrm{C}\right)$ and a 12 hour day and night cycle. Seeds were removed from 50 petri dishes once a perceptible radicle emerged. The experiment ceased after five days with no further 51 germination. No pre-treatment of seeds was required for the selected species to break dormancy (Schmidt 52 2000; Turnbull \& Martensz 1982).

53 For controlled experiments on seed-soil relations the osmotic water potential can be used to represent soil 54 matric potential (Carpita et al. 1979; Gray et al. 1990; McWilliam \& Phillips 1971). We used solutions of polyethylene glycol (PEG 6000) to expose seeds to nine osmotic water potentials: 0, -.01, -.03, -.1, -.25, $-.5,-.75,-1$, and $-1.5 \mathrm{MPa}$. These values capture soil water conditions ranging from water saturation $(0$ $\mathrm{kPa}$ ) and field capacity (-.01 to $-.03 \mathrm{MPa})$ to the permanent wilting point (-1.5 MPa). The empirical equation derived by Michel \& Kaufmann (1973) and revised by (Wood et al. 1993) was used to set up the 59 required water potential $(\psi$ in $\mathrm{kPa})$ :

$$
\psi=\left(6.310^{-5} T-0.02196\right) O^{2.2357},
$$

where $T$ is the temperature in $\mathrm{K}$ (here $298.15 \mathrm{~K}$ ), and $O$ denotes the osmolality in $\mathrm{g} 1,000 \mathrm{~g} \mathrm{~g}^{-1}$ of water. Solutions measuring $15 \mathrm{ml}$ of PEG 6000 were added to the seeds on the Wettex ${ }^{\circledR}$ substrate within a $90 \mathrm{~mm}$ petri dish and wrapped with Parafilm ${ }^{\circledR}$ to prevent evaporation. The dishes were opened each day to provide aeration and to count and remove germinated seeds.

\subsection{Germinability and mean germination time}

We used germinability $G(\%)$ and mean germination time (days) as measurements to quantify germination (Ranal \& Santana 2006). While $G$ simply represents the number of germinated seeds $(g)$ relative to the total number of seeds per replicate $(n)$ :

$$
G=(g / n) 100 \text {, }
$$

$71 \quad ' t=\sum_{i=1}^{k} g_{i} t_{i} / \sum_{i=1}^{k} g_{i}$

72 where $t_{i}$ is the time elapsed from initiation of the experiment to the $i^{\text {th }}$ observation day until germination 73 ceases on the $k^{\text {th }}$ day.

11 Seeds were collected in November 2012 from the native Brigalow catchment at the Brigalow Research

2 Station (Cowie et al., 2007). 
We applied a generalised logistic regression model (GLM) on a logit scale and simple linear

75

76

77

78

79

80

81

82

83

84

85

86

87

88

89

90

91

92

93

94

95

96

97

98

99

100

101

102

103

104

105

106

107

108

regression for $G$ and ${ }^{\prime}$, respectively, to test the significance of the relationship between germination percentage or time required for maximum germination and decreasing water potential. Assumptions were tested via diagnostic plots, which showed no violation of homogeneity of variance and normal distribution for the residuals. Separate GLM models were adopted for each species as this provided the best fit for the data. We also employed other models (linear regression and logistic regression with a probit scale) and various transformations (arcsine, square root transformations) but they either did not fit the data, or when they did, failed homogeneity of variance and normal distribution of error $(p>0.05)$.

We compared the results for $G$ with those published by Reichman et al. (2006) for salinity. Therefore, we estimated the osmotic pressure $\psi_{o}(\mathrm{MPa})$ based on the value range of electrical conductivity used in Reichman 2006:

$$
\psi_{o}=M R T \text {, }
$$

where $M$ is the molarity ( $\mathrm{mol} \mathrm{L}^{-1}$ ) of the sodium chloride solution, $T$ is the temperature in $\mathrm{K}$ (here 298.15 $\mathrm{K})$, and $R$ is the gas constant $\left(\mathrm{J} \mathrm{mol}^{-1} \mathrm{~K}^{-1}\right)$. The corresponding values of $\psi_{o}$ are presented in Table 1 .

\subsection{Estimating parameters of the hydrotime model}

The hydrotime model was proposed by (Bradford 1990; Gummerson 1986) to "simultaneously account for both the timing and the extent of germination of a given seed population in relation to its $\psi$ environment" (Bradford 2002). It is defined as:

$$
\theta_{H}=\left(\psi-\psi_{b}(P)\right) t_{P}
$$

where $\theta_{H}$ is the hydrotime constant (MPa hr), $t_{P}(\mathrm{hr})$ is the time to germination of percentage $P$ of the seed population, and $\psi_{b}(P)(\mathrm{MPa})$ is the base or threshold water potential above which $P$ can still complete germination. Among the seed population, $\psi_{b}$ is variable and can be described by a range of frequency distributions (Mesgaran et al. 2013) of which the normal frequency distribution is the most commonly used one, defined by its mean $\psi_{b}\left(P_{50}\right)$ and standard deviation $\sigma_{\psi b}$ (Gummerson 1986). Together, these parameters enable prediction of the germination time courses, i.e. both rate and extent of germination of the seed population, at any $\psi$ at a constant temperature (Bradford 2002):

$$
t_{P}=\theta_{H} /\left(\psi-\psi_{b}\left(P_{50}\right)\right) \text {. }
$$

In this regard, $\theta_{H}$ "quantifies the inherent speed of germination, which can vary among species and physiological states" (Bradford 2002), whereas $\psi_{b}\left(P_{50}\right)$ indicates the average stress tolerance of a seed population, and $\sigma_{\psi b}$ describes the synchrony in germination timing among seeds in a population. We estimated these parameters based on the observed values of $t_{P}$ for each $\psi$, i.e. we plotted the germination rates $\left(1 / t_{P}\right.$ in $\left.\mathrm{hr}^{-1}\right)$ as a function of $\psi$ and fitted regressions to the observed data (Fig. 4). This resulted in straight lines with slopes of $\theta_{H}^{-1}$ and intercepts on the $\psi$-axis corresponding with $\psi_{b}(P)$. The values of $\psi_{b}(P)$ were then fitted to a normal and log-logistic frequency distribution, respectively, and their distribution parameters were estimated accordingly. 
109

110

111

112

113

114

115

116

117

118

119

120

121

122

123

124

125

\section{Results}

Spearman's correlation coefficient of -0.96 indicated a significant $\left(p=10^{-4}\right)$ negative correlation between mean time required for maximum germination and germinability (Fig. 1). Above -.75 MPa germinability was remarkably large and mean germination time small. The mean time required for maximum germination ranged between three and five days at water potentials higher than $-.75 \mathrm{MPa}$ and increased to over seven days at water potentials lower than -1 MPa (Fig.2b). Likewise, germinability was highest $(90 \% \pm 9 \%)$ at the water potential corresponding to saturated soil water conditions $(0 \mathrm{MPa})$ and significantly decreased with decreasing water potential $(\mathrm{p}=0.003)$ to $65 \% \pm 11 \%$ and $20 \% \pm 9 \%$ at water potentials of -,75 MPa and -1 MPa, respectively (Fig. 2a). Remarkably, at a water potential as low as -1.5 $\mathrm{MPa}$ (permanent wilting point) still $4 \% \pm 1.8 \%$ of the seeds germinated. Accordingly, the estimated mean base water potentials were $-1.533 \mathrm{MPa}$ and $-1.451 \mathrm{MPa}$ for the normal and log-logistic distribution, respectively (Fig. 3), and the estimated hydrotime constant was .0607 MPa h (Table 2).

In figure 4 we plotted the germinability of Brigalow seeds in relation to the osmotic pressure based on solutions of sodium chloride as applied by Reichman et al. (2006), and solutions of Polyethylene Glycol as applied in this study. While no significant differences $(p<0.05)$ were observed between the two treatments for osmotic pressures above $-.4 \mathrm{MPa}$, germinability was smaller under the sodium chloride treatment for osmotic pressures below -.4 MPa. 


\section{Discussion}

The findings of this study allude to the seed water condition of $A$. harpophylla. Together with the initial soil water conditions, these state variables have crucial implications for the rehabilitation of postmining areas under water-limited conditions.

\subsection{Soil and seed water conditions}

Initial soil water conditions play a critical role when direct seeding is the primary approach to revegetating post-mining areas. This is even more important in a semi-arid climate, where water is limited due its scarcity or erratic occurrence (Rodriguez-Iturbe \& Proporato 2004). Seed germination is triggered by the amount of water the seed can imbibe, which is related to the water potentials of both the soil and the seed (Bewley et al. 2013; Bradford 2002; Evans \& Etherington 1990; Williams \& Shaykewich 1971). In this regard, water can only enter the seed if the seed water potential is below the water potential of the surrounding soil material. In general, air-dry seeds have water potential values of -50 to $-350 \mathrm{MPa}$ (Bewley et al. 2013). The empirical results of this study indicate that seeds of A. harpophylla are very water stress tolerant, that is, their seed water potential is extraordinarily low. For example, radicles still emerged at a water potential as low as $-1.5 \mathrm{MPa}$ (Fig. 2a). Likewise, the mean base water potential of the seed population ranges between -1.533 MPa and -1.451 MPa (Table 2 and Fig. 3). These are remarkable values compared with selected Mediterranean (Köchy \& Tielbörger 2007) ${ }^{2}$ and agricultural plant species (Watt et al. 2011) ${ }^{3}$. Qualitatively, the low seed water potential corresponds well with other investigative studies on physiological water relations of $A$. harpophylla (Doley 2004), which measured foliage water potentials as low as $-15 \mathrm{MPa}$ (Connor \& Tunstall 1968) and shoot water potentials of -7.2 to $-6.8 \mathrm{MPa}$ (Connor et al. 1971; Tunstall \& Connor 1981; Van den Driessche et al. 1971). Also the seed coat, which is atypically soft compared with other Acacia species, denotes an adaptive mechanism to erratic rainfall patterns of the Brigalow Belt Bioregion to rapidly overcome dormancy if soil water conditions are elevated (Johnson 1964; Reichman et al. 2006; Scott et al. 1984).

The parameter estimates of the hydrotime model (Table 2) play a critical role for predicting the time required to germinate a fraction of the seed population under given soil water conditions (Eq. $5 \mathrm{~b}$ ). In this regard and together with the physiological parameters of the hydrotime model (i.e., hydrotime constant and distribution of the base water potential) the soil water potential governs germination and, consequently, the success of initial vegetation recruitment and early ecosystem establishment. Moreover, together with empirical data on the effect of temperature on the germination of Brigalow seeds (Reichman et al. 2006), the findings of this study can be utilised to parameterise hydrothermal models (Bradford 2002; Bullied et al. 2012; Gummerson 1986; Köchy \& Tielbörger 2007; Watt et al. 2011) for predictive modelling of germination in relation to the two environmental factors of temperature and water availability.

The results of this study show that germinability decreases and the time required for maximum germination increases with decreasing soil water potential (Fig. 2). Moreover, the strong negative correlation between germinability and mean germination time (Fig. 1) underpins how important a rather short germination time is to maximise germination success. Thus, topsoil restoration at post-mining land in the Brigalow Belt Bioregion should target to maximise the initial soil water potential while explicitly considering the erratic character of rainfall patterns in Central Queensland (Audet et al. 2013; $\underline{\text { Audet et al. }}$ 2012). This can be accomplished by optimising soil attributes such as depth, texture, compaction, organic

$2 \psi_{b}\left(P_{50}\right)=-1.39--.59 \mathrm{MPa}$ (based on 36 species)

$3 \psi_{b}\left(P_{50}\right)=-1.42--1.13 \mathrm{MPa}$ (based on 4 species) 

restoration, pre-treatment of seeds, i.e. seed priming, also plays a critical role to enhance germination (Jisha et al. 2013). Amongst the broad range of seed priming techniques, hydropriming and osmopriming are the most promising approaches for plant establishment in semi-arid climate to increase seedling growth (Yagmur \& Kaydan 2008), and root and shoot length (Kaur et al. 2002). Although the exact mechanisms behind pre-treatments of seeds are not fully understood, seed priming seems to activate cell signalling pathways and cellular responses to environmental stressors resulting in faster plant defence responses ( $\underline{\text { jisha et al. 2013). }}$.

Despite plant available water being the primary environmental factor in the Brigalow Belt Bioregion (Arnold et al. 2013), due to hot summers and highly saline mine spoils secondary stressors such as temperature and salinity may also play a critical role for the germination success of A. harpophylla, which was tested by Reichman et al. (2006). Their findings indicate no significant trend in germination among the temperature range of $15-38^{\circ} \mathrm{C}^{4}$. Likewise, seeds of $A$. harpophylla showed remarkable tolerance to salinity up to an electrical conductivity of $30 \mathrm{dS} \mathrm{m} \mathrm{m}^{-1}$, however, with significant reduction in germination at salinity greater than $20 \mathrm{dS} \mathrm{m}^{-1}$. The authors speculated "it seems unlikely that the reduced germination at 25 and $30 \mathrm{dS} / \mathrm{m}$ were due to osmotic effects" (Reichman 2006). While the present study confirms this conclusion for high values of salinity (Table 1) corresponding to osmotic pressure values greater than -.4 MPa (Fig. 4), no significant differences could be found between treatments of sodium chloride and PEG (section 2) for small values of osmotic pressure corresponding to high salinity (Fig. 4). That said, we conclude that under low to moderate levels of salinity the osmotic pressure plays the primary role for germination of $A$. harpophylla seeds rather than the toxic nature of the predominant salt (here sodium chloride), whereas salinity becomes the primary environmental stressor under high salt concentrations. More generally, seeds of A. harpophylla seem to germinate quite uniformly over a broad range of environmental conditions related to temperature, salinity, and water availability ${ }^{5}$.

\subsection{Alternative rehabilitation approaches}

Despite the opportunistic germination capability of $A$. harpophylla seeds, the question remains whether direct seeding denotes the optimal approach to rehabilitate native Brigalow ecosystems given the hydropedological ${ }^{6}$, climatic, and plant physiological attributes and conditions of the Brigalow Belt Bioregion.

Hydropedological processes are fundamental for the proliferation of Brigalow plant communities (Arnold et al. 2013). The predominant clay soils (Isbell 2002) comprise fine-textured non-cracking Grey and Black Dermosols (Lixisols (Rees et al. 2010; WRB 2006)), and uniform dark cracking Grey and Black Vertosols (Vertisols (Rees et al. 2010)). The latter form "gilgais" (Cowie et al. 2007; Radford et al. 2007; Thornton et al. 2007), which denote ephemeral water storages if filled during intensive storm

201

202

203

204

205

206 events. The climate is characterised by erratically distributed rainfall patterns with short and intensive storm events occurring during summer (Cowie et al. 2007), associated with the risk of water logging or soil erosion; whereas the very arid conditions during the winter season generally involve periods of water deficit (Audet et al. 2013; Audet et al. 2012; Dalton 1993). In combination with these erratic climatic conditions the soil properties facilitate rather low soil water potentials on the long-term (Tunstall \& Connor 1981), and as a consequence, these landscapes can be colonised by a few plant species only, which

$54 G=90 \%$ after 14 days

65 Note that soil hydraulic conductivity can become a limiting factor in dry soils (Bewley et al. 2013).

76 interface between the pedosphere and the hydrosphere (Li et al. 2012) 
207 is reflected in relatively low species richness and total vegetative biomass (Isbell 2002; Johnson 1980). As

208 elaborated in the previous section, among the species in the Brigalow Belt Bioregion, A. harpophylla

209 developed very well adapted mechanisms to proliferate under these harsh conditions. The plants flower

210 only sporadically (Benson et al. 2006) and thus seeds and seedlings are only produced in large numbers

211 during years of extraordinary rainfall (Butler 2007; Johnson 1997). However, A. harpophylla is able to

212 reproduce asexually, i.e. through root suckering or sprouting even if aboveground parts of the plant are

213 damaged dramatically, as long as belowground biomass and hydropedology stay intact (Arnold et al.

214 (2013) and references therein). The extent of this vegetative reproduction is most pronounced if trees are

215 young and severely damaged, and under dry conditions (Johnson 1964). In Colorado (USA) circumstances

216 are similar with regard to the re-establishment of vegetatively regenerating Aspen (Populus tremuloides)

217 on surface-mined land (Musselman et al. 2012), which initially failed due to severe damage to the root

218 system and thus the limited access to water and nutrients (Shepperd \& Mata 2005). However,

219 rehabilitation was more successful when more comprehensive soil-root compartments were transplanted

220 from local sources in combination with weed control and light irrigation with non-saline water

221 (Musselman et al. 2012). In this regard, it seems to be crucial to keep the delicate balance between soil

222 attributes (depth, compaction, texture) and root extension in balance. This innovative rehabilitation

223 approach of transplanting the whole soil-root compartment may also be of interest for restoration

224 ecologists engaged with re-establishment of Brigalow ecosystems in Central Queensland to achieve safe,

225 stable, and non-polluting ecosystems (Australian Government 2006). However, the advantage of direct

226 seeding over asexual propagation such as transplantation is the gain of genetic diversity - critical if

227 ecosystems are forced to adapt to the projected changing climate of Central Queensland (Low 2011). 


\section{Acknowledgments}

229 The authors would like to thank Steve Adkins and David Doley for critical discussions, as well as the two

230 reviewers Ana Vasques and Teresa Eyre for constructive comments. Further, we thank Stuart Irvine-Brown

231 for collection of $A$. harpophylla seeds - a pivotal contribution to this study. 


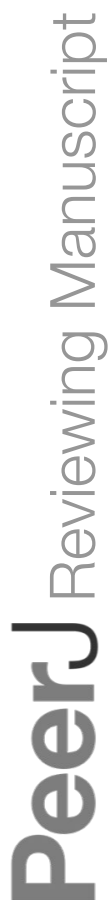

PeerJ reviewing PDF | (v2013:10:872:1:0:NEW 10 Jan 2014) 


\section{References}

233

234

235

236

237

238

239

240

241

242

243

244

245

246

247

248

249

250

251

252

253

254

255

256

257

258

259

260

261

262

263

264

265

266

267

268

269

270

271

272

273

274

275

276

277

278

279

280

281

282

283
Arnold S. 2012. Finding optimal soil restoration strategies in the face of uncertain future rainfall amount. Proceedings of the Life-of-Mine Conference. Brisbane: The Australasian Institute of Mining and Metallurgy. p 91-95.

Arnold S, Audet P, Doley D, and Baumgartl T. 2013. Hydropedology and ecohydrology of the Brigalow Belt, Australia: opportunities for ecosystem rehabilitation in semi-arid environments. Vadose Zone Journal.

Audet P, Arnold S, Lechner AM, and Baumgartl T. 2013. Site-specific climate analysis elucidates revegetation challenges for post-mining landscapes in eastern Australia. Biogeosciences 10:6545-6557.

Audet P, Arnold S, Lechner AM, Mulligan DR, and Baumgartl T. 2012. Climate suitability estimates offer insight into fundamental revegetation challenges among post-mining rehabilitated landscapes in eastern Australia. Biogeosciences Discuss 9:18545-18569.

Australian Government. 2006. Mine closure and completion. Canberra.

Benson JS, Allen CB, Togher C, and Lemmon J. 2006. New South Wales vegetation classification and assessment: Part 1 Plant communities of the NSW Western Plains. Cunninghamia 9:383-450.

Bewley JD, Bradford KJ, Hilhorst HW, and Nonogaki H. 2013. Seeds. Physiology od Development, Germination and Dormancy. Springer.

Bradford KJ. 1990. A Water Relations Analysis of Seed Germination Rates. Plant Physiology 94:840-849.

Bradford KJ. 2002. Applications of hydrothermal time to quantifying and modeling seed germination and dormancy. Weed Science 50:248-260.

Bullied WJ, Van Acker RC, and Bullock PR. 2012. Hydrothermal Modeling of Seedling Emergence Timing across Topography and Soil Depth. Agronomy Journal 104:423-436.

Butler DW. 2007. Recovery plan for the "Brigalow (Acacia harpophylla) dominant and codominant" endangered ecological community. Brisbane: Queensland National Parks and Wildlife Service.

Carpita N, Sabularse D, Montezinos D, and Delmer DP. 1979. Determination of the Pore Size of Cell Walls of Living Plant Cells. Science 205:1144-1147.

Connor D, and Tunstall B. 1968. Tissue water relations for Brigalow and Mulga. Australian Journal of Botany 16:487-490.

Connor DJ, Tunstall BR, and Van den Driessche R. 1971. Analysis of photosynthetic response in a Brigalow forest. Photosynthetica 5:218-\&.

Cowie BA, Thornton CM, and Radford BJ. 2007. The Brigalow Catchment Study: I. Overview of a 40-year study of the effects of land clearing in the brigalow bioregion of Australia. Australian Journal of Soil Research 45:479-495.

Czabator FJ. 1962. Germination value: an index combining speed and completeness of pine seed germination. Forest Science 8.

Dalton GS. 1993. Direct seeding of trees and shrubs: A manual for Australian conditions. Primary Industries (SA).

DEWHA. 2010. Brigalow (Acacia harpohylla) Dominant and Co-dominant. In: Department for Environment Water Heritage and the Arts, editor.

Doley D. 2004. Evolution of plant water relations research in Australia. Functional Plant Biology 31:405-414.

Engel VL, and Parrotta JA. 2001. An evaluation of direct seeding for reforestation of degraded lands in central São Paulo state, Brazil. Forest Ecology and Management 152:169-181.

Evans CE, and Etherington JR. 1990. The effect of soil water potential on seed germination of some British plants. New Phytologist 115:539-548.

Eyre TJ, Wang J, Venz MF, Chilcott C, and Whish G. 2009. Buffel grass in Queensland's semiarid woodlands: response to local and landscape scale variables, and relationship with grass, forb and reptile species. Rangeland Journal 31:293-305. 
284

285

286

287

288

289

290

291

292

293

294

295

296

297

298

299

300

301

302

303

304

305

306

307

308

309

310

311

312

313

314

315

316

317

318

319

320

321

322

323

324

325

326

327

328

329

330

331

332

333

334

335

336
Gray D, Steckel JRA, and Hands LJ. 1990. Responses of Vegetable Seeds to Controlled Hydration. Annals of Botany 66:227-235.

Gummerson RJ. 1986. The Effect of Constant Temperatures and Osmotic Potentials on the Germination of Sugar Beet. Journal of Experimental Botany 37:729-741.

Gunn RH. 1984. Soil landscapes of the Brigalow Belt in Queensland. In: Bailey A, editor. The Brigalow Belt of Australia. Brisbane: The Royal Society of Queensland. p 7-21.

Isbell RF. 2002. The Australian Soil Classification - revised edition. In: Publishing C, editor. Collingwood, Australia.

Jisha KC, Vijayakumari K, and Puthur JT. 2013. Seed priming for abiotic stress tolerance: an overview. Acta Physiologiae Plantarum 35:1381-1396.

Johnson RW. 1964. Ecology and control of Brigalow in Queensland. Brisbane, Queensland, Australia: Queensland Department of Primary Industries.

Johnson RW. 1980. Studies of a vegetation transect through Brigalow (Acacia harpophylla) forest in Central Queensland. Australian Journal of Ecology 5:287-307.

Johnson RW. 1997. The impact of clearing on brigalow communities and consequences for conservation. In: Hale P, and Lamb D, eds. Conservation outside nature reserves. Brisbane: The University of Queensland, 359-363.

Kaur S, Gupta A, and Kaur N. 2002. Effect of osmo- and hydropriming of chickpea seeds on seedling growth and carbohydrate metabolism under water deficit stress. Plant Growth Regulation 37:17-22.

Köchy M, and Tielbörger K. 2007. Hydrothermal time model of germination: Parameters for 36 Mediterranean annual species based on a simplified approach. Basic and Applied Ecology 8:171-182.

Lamb D, Erskine PD, and Parrotta JA. 2005. Restoration of degraded tropical forest landscapes. Science 310:1628-1632.

Li X-Y, Lin H, and Levia DF. 2012. Chapter 23 - Coupling Ecohydrology and Hydropedology at Different Spatio-Temporal Scales in Water-Limited Ecosystems. Hydropedology. Boston: Academic Press, 737-758.

Lloyd PL. 1984. The climatic environment of the Brigalow Belt of Queensland. In: Bailey A, editor. The Brigalow Belt of Australia. Brisbane: The Royal Society of Queensland. p 2340.

Low T. 2011. Climate change and Queensland Biodiversity. Department of Environment and Heritage Protection, Queenlands Government.

McWilliam J, and Phillips P. 1971. Effect of Osmotic and Matric Potentials on the Availability of Water for Seed Germination. Australian Journal of Biological Sciences 24:423-432.

Mesgaran MB, Mashhadi HR, Alizadeh H, Hunt J, Young KR, and Cousens RD. 2013. Importance of distribution function selection for hydrothermal time models of seed germination. Weed Research 53:89-101.

Michel BE, and Kaufmann MR. 1973. The Osmotic Potential of Polyethylene Glycol 6000. Plant Physiology 51:914-916.

Musselman RC, Shepperd WD, Smith FW, Asherin LA, and Gee BW. 2012. Response of transplanted aspen to irrigation and weeding on a Colorado reclaimed surface coal mine. Fort Collins, CO: Res. Pap. RMRS-RP-101 U.S. Department of Agriculture, Forest Service, Rocky Mountain Research Station. p 20.

Radford BJ, Thornton CM, Cowie BA, and Stephens ML. 2007. The Brigalow Catchment Study: III. Productivity changes on brigalow land cleared for long-term cropping and for grazing. Australian Journal of Soil Research 45:512-523.

Ranal MA, and Santana DGd. 2006. How and why to measure the germination process? Brazilian Journal of Botany 29:1-11.

Rees D, Boucher S, Imhof M, Holland J, and Robinson N. 2010. Classifying sodic soils: A comparison of the World Reference Base for soil resources and Australian Soil Classification systems. 19th World Congress of Soil Science: Soil Solutions for a changing World. Brisbane: International Union of Soil Sciences. p 23-26. 
337

338

339

340

341

342

343

344

345

346

347

348

349

350

351

352

353

354

355

356

357

358

359

360

361

362

363

364

365

366

367

368

369

370

371

372

373
Reichman SM, Bellairs SM, and Mulligan DR. 2006. The effects of temperature and salinity on Acacia harpophylla (brigalow) (Mimosaceae) germination. Rangeland Journal 28:175178.

Rodriguez-Iturbe I, and Proporato A. 2004. Ecohydrology of water-controlled ecosystems. Cambridge Univ Press.

Schmidt L. 2000. Guide to handling of tropical and subtropical forest seed. . Danida Forest Seed Centre.

Scott SJ, Jones RA, and Williams WA. 1984. Review of Data Analysis Methods for Seed Germination1. Crop Sci 24:1192-1199.

Shepperd WD, and Mata SA. 2005. Planting aspen to rehabilitate riparian areas: a pilot study. Fort Collins, CO: US Department of Agriculture, Forest Service, Rocky Mountain Research Station. p 5.

Thornton CM, Cowie BA, Freebairn DM, and Playford CL. 2007. The Brigalow Catchment Study: II. Clearing brigalow (Acacia harpophylla) for cropping or pasture increases runoff. Australian Journal of Soil Research 45:496-511.

Tunstall BR, and Connor DJ. 1981. A hydrological study of a sub-tropical semi-arid forest of Acacia harpophylla F Muell ex Benth (Brigalow). Australian Journal of Botany 29:311320.

Turnbull JW, and Martensz PN. 1982. Aspects of seed collection, storage and germination in Casuarinaceae. Australian Forest Research 12:281-294.

Van den Driessche R, Connor DJ, and Tunstall BR. 1971. Photosynthetic response of Brigalow to irradiance, temperature and water potential. Photosynthetica 5:210-\&.

Watt MS, Bloomberg M, and Finch-Savage WE. 2011. Development of a hydrothermal time model that accurately characterises how thermoinhibition regulates seed germination. Plant Cell and Environment 34:870-876.

Williams J, and Shaykewich CF. 1971. Influence of Soil Water Matric Potential and Hydraulic Conductivity on the Germination of Rape (Brassica napus L.). Journal of Experimental Botany 22:586-597.

Wood I, Dart I, and So H. 1993. Measurement of the total water potential of aqueous solutions of polyethylene glycol - A comparison between osmometer, thermocouple psychrometer and equilibrated soil cores. Soil Research 31:1-11.

WRB IWG. 2006. World reference base for soil resources. In: Reports WSR, editor. Rome: FAO.

Yagmur M, and Kaydan D. 2008. Alleviation of osmotic stress of water and salt in germination and seedling growth of triticale with seed priming treatments. Afr J Biotechnol 7:21562162.

Zipper CE, Burger JA, Barton CD, and Skousen JG. 2013. Rebuilding Soils on Mined Land for Native Forests in Appalachia. Soil Sci Soc Am J 77:337-349. 


\section{Table 1 (on next page)}

Osmotic pressure $\psi \mathrm{O}$ and $\mathrm{NaCl}$ concentration based on the electrical conductivity used in Reichman et al. (2006). 
Table 1. Osmotic pressure $\psi_{o}$ and $\mathrm{NaCl}$ concentration based on the electrical conductivity used in Reichman et al. (2006).

\begin{tabular}{lll}
\hline $\begin{array}{l}\text { Electrical conductivity } \\
\left(\mathbf{d S ~ ~ m ^ { - 1 }}\right)^{\boldsymbol{\pi}}\end{array}$ & $\begin{array}{l}\mathbf{N a C l ~ c o n c e n t r a t i o n ~} \\
\left(\mathbf{g ~ k g}^{-1} \mathbf{H}_{\mathbf{2}} \mathbf{O}\right)^{\S}\end{array}$ & $\begin{array}{l}\text { Osmotic pressure } \\
\psi_{o}(\mathbf{M P a})\end{array}$ \\
\hline 0 & 0 & 0 \\
5 & 1.17 & -.05 \\
10 & 4.57 & -.195 \\
15 & 6.86 & -.293 \\
20 & 9.14 & -.391 \\
25 & 11.43 & -.489 \\
30 & 13.7 & -.586 \\
\hline
\end{tabular}

I - Reichman et al. (2006)

$\S$ - Salinity Laboratory Staff (1954) 


\section{Table 2 (on next page)}

\section{Parameters estimates}

Parameters estimates of the the hydrotime constant (Bradford 2002), and the log-logistic distribution (scale $\alpha$, shape $\beta$ ) and normal distribution (mean $\mu$, standard deviation $\sigma$ ) based on the germination trials of $A$. harpophylla. 
Table 2. Parameters estimates of the the hydrotime constant (Bradford 2002), and the log-logistic distribution (scale $\alpha$, shape $\beta$ ) and normal distribution (mean $\mu$, standard deviation $\sigma$ ) based on the germination trials of $A$. harpophylla.

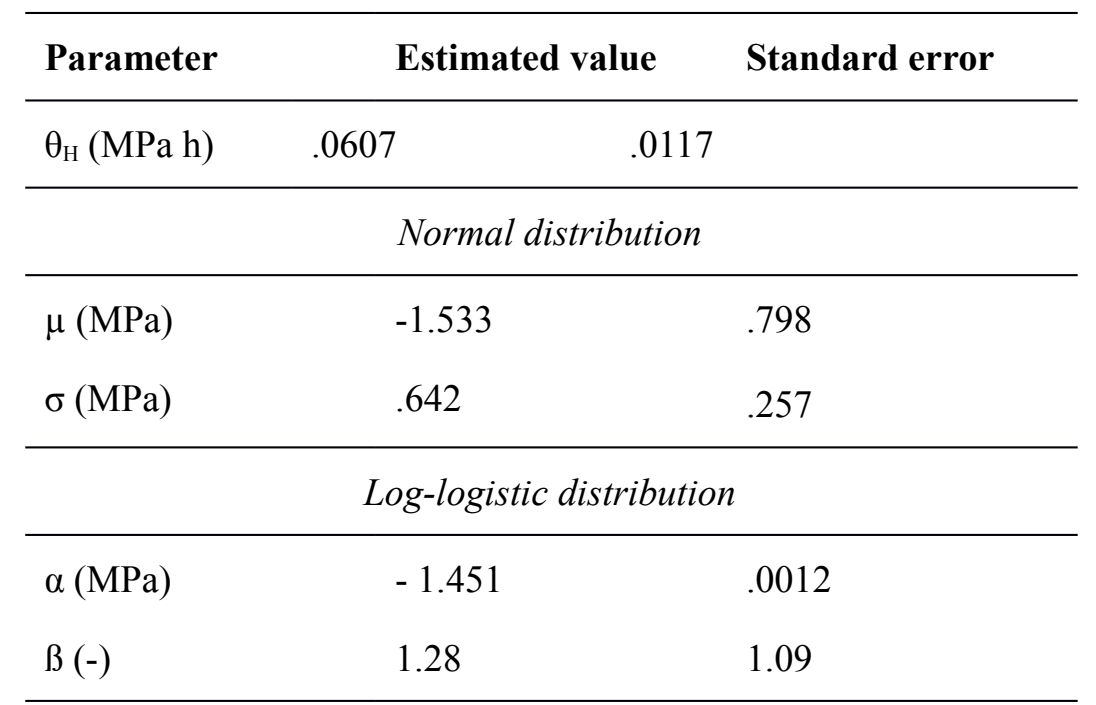




\section{Figure 1}

Negative correlation between mean germination time and germinability. Spearman's correlation coefficient $r s$ is significantly different from zero $\left(p=10^{-4}\right)$.

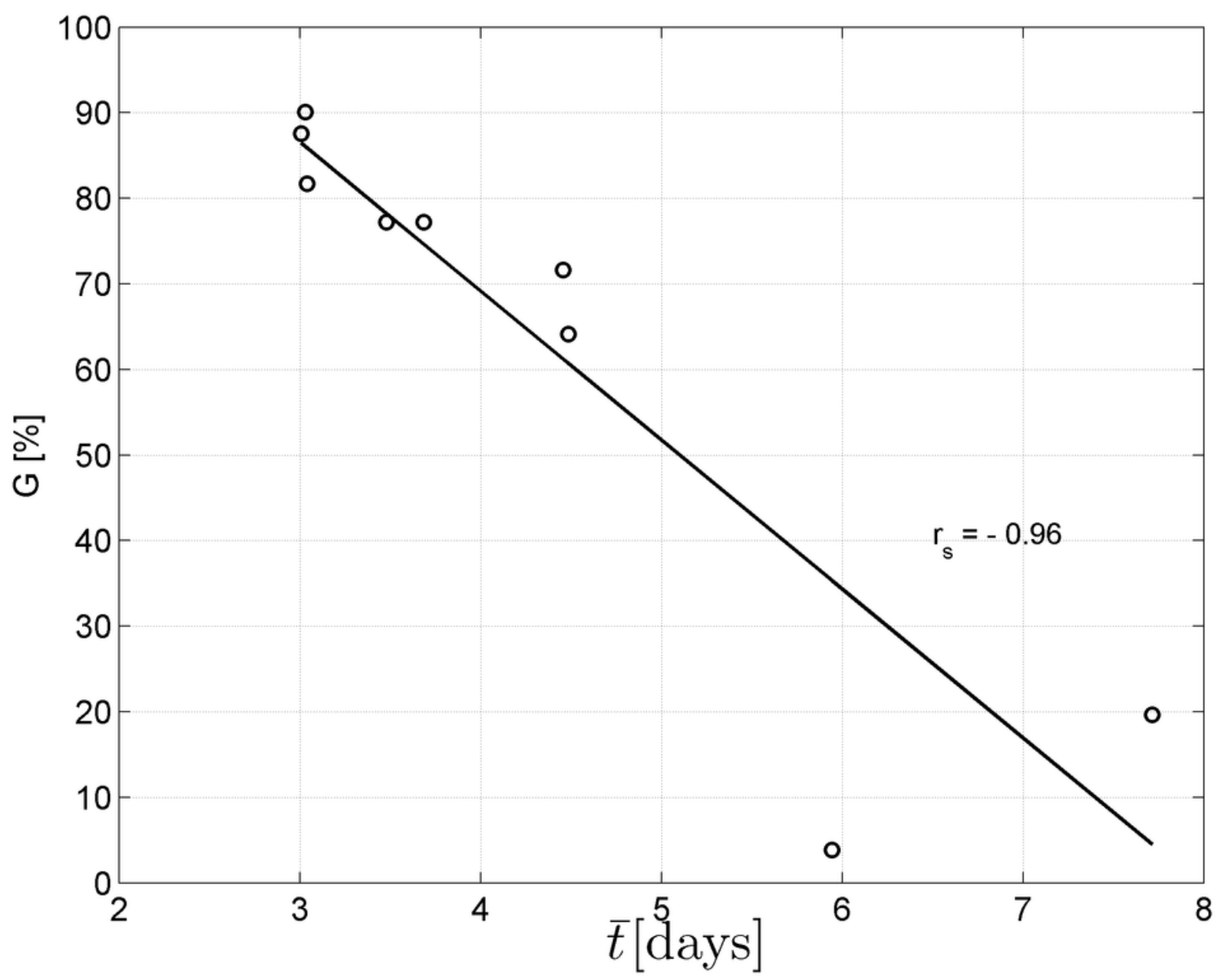




\section{Figure 2}

Germination results

(a) Germinability $G$ and (b) time required for maximum germination $\mathrm{t}$ of $A$. harpophylla in relation to the water potential $\psi$. Error bars indicate the standard deviation across 3 replicates of 50 seeds.
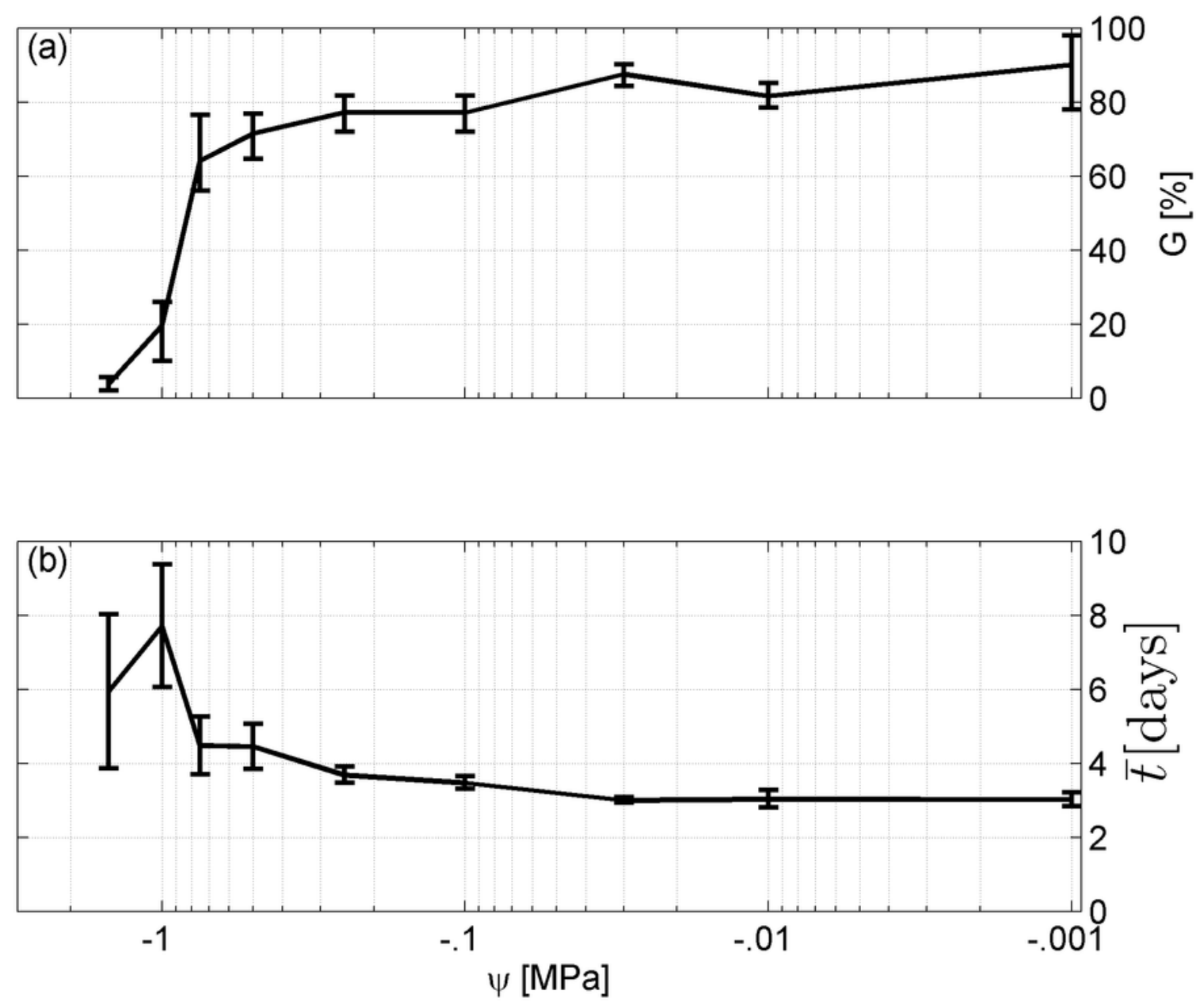


\section{Figure 3}

Hydrotime model - parameters

Germination rate in relation to water potential $\psi$ (adapted according to Bradford (2002)). While the slopes of the curves correspond to the reciprocal of the hydrotime constant $\theta_{H^{-1}}{ }^{-1}$, the interceptions with the $\psi$-axis correspond to the base water potential $\psi \mathrm{b}$ for a given percentage $P$ of the seed population. The values of $\psi_{b}$ can be described by a range of frequency distributions (Mesgaran et al. 2013) among the seeds of a lot (inset). Parameter estimates of the log-logistic $(\alpha, \beta)$ and normal distribution $(\mu, \sigma)$, and $\theta_{H}$ are presented in

Table 2.
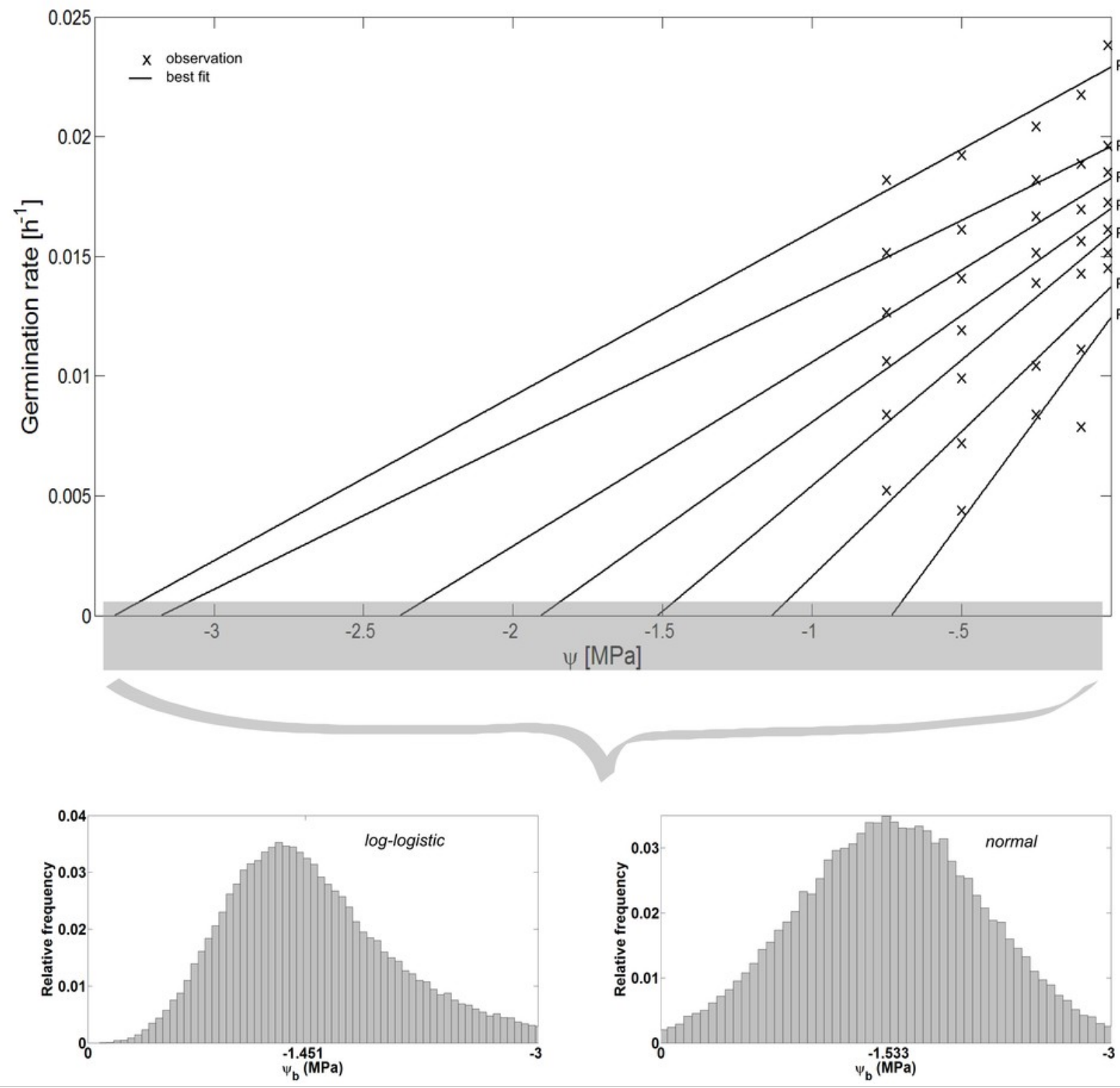


\section{Figure 4}

Water potential vs salinity

Germinability $\mathrm{G}$ of $A$. harpophylla in relation to the osmotic pressure $\psi_{0}$ based on solutions of sodium chloride (squares (Reichman et al. 2006)) and PEG (crosses). Error bars indicate the standard error across 4 replicates of 20 seeds (Reichman et al. 2006) and 3 replicates of 50 seeds for salinity and soil water potential, respectively.

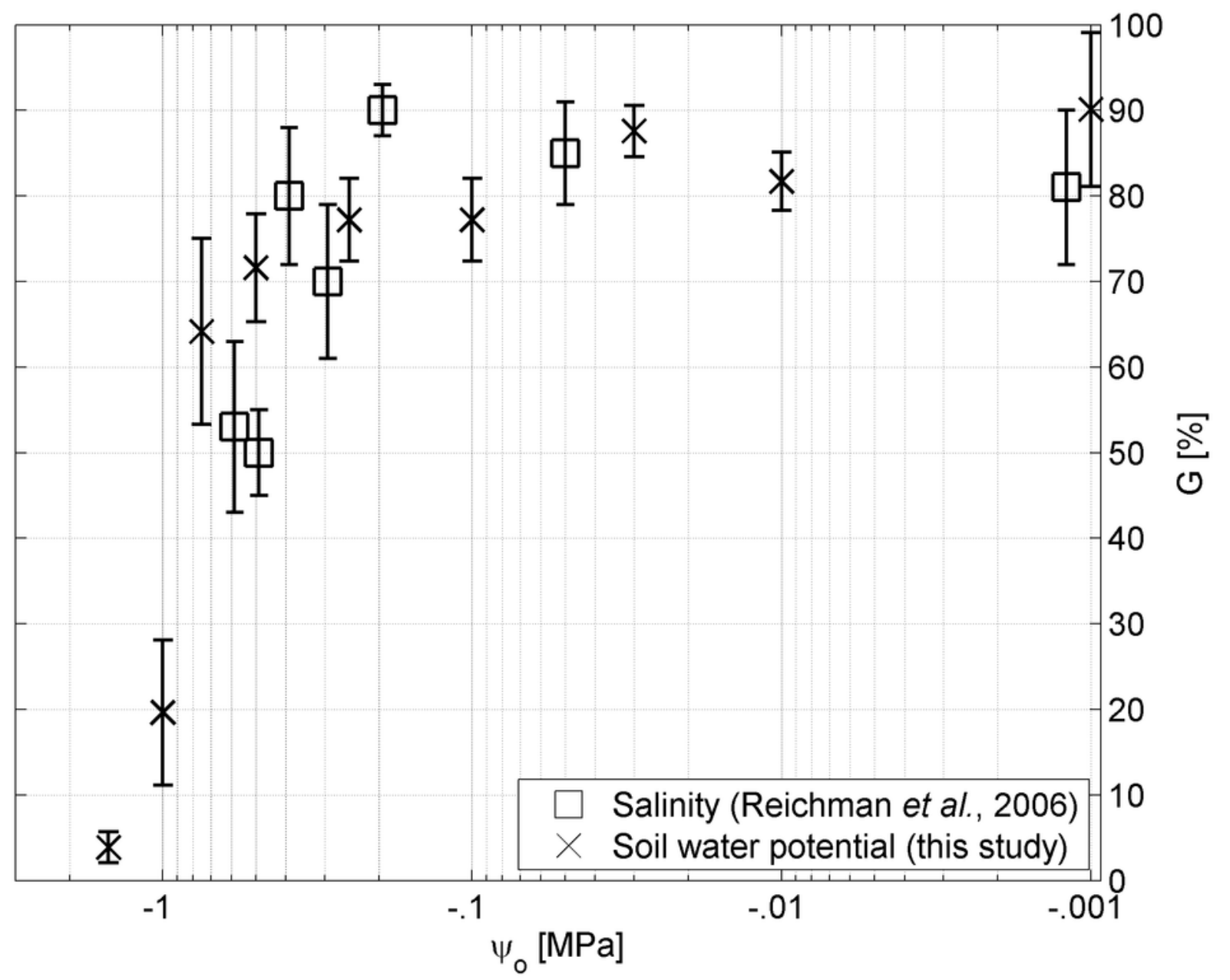

